\title{
Presence of multiple acid phosphatases activity in seedlings of cucumber, radish and rocket salad
}

\author{
Presença de atividade de múltiplas fosfatases ácidas em plântulas de pepino, rabanete e rúcula
}

\author{
Luciane Almeri Tabaldi ${ }^{\mathrm{I}}$ Raquel Ruppenthal ${ }^{\mathrm{I}}$ Luciane Belmonte Pereira ${ }^{\mathrm{I}}$ Denise Cargnelutti ${ }^{\mathrm{I}}$ \\ Jamile Fabbrin Gonçalves ${ }^{\mathrm{I}}$ Vera Maria Morsch ${ }^{\mathrm{I}}$ Maria Rosa Chitolina Schetinger ${ }^{\mathrm{I} *}$
}

\section{ABSTRACT}

Acid phosphatases (3.1.3.2) are a group of enzymes widely distributed in nature, which catalyze the hydrolysis of a variety of phosphate esters in the $\mathrm{pH}$ range of 4-6. We confirmed the presence of acid phosphatases in seedlings of cucumber (Cucumis sativus), radish (Raphanus sativus) and rocket salad (Eruca vesicaria) under different assay conditions using a rapid and simple preparation. The results showed that the optimum $\mathrm{pH}$ and temperature used for all species were close to 5.5 and $35^{\circ} \mathrm{C}$, respectively. The enzyme was inhibited by molybdate, fluoride, azide, levamisole, orthovanadate, $\mathrm{Zn}^{2+}$ and $\mathrm{Cu}^{2+}$. Suramin had no effect on enzyme activity. The acid phosphatase from cucumber, radish and rocket salad hydrolyzed a wide variety of phosphate esters and the highest activity was observed with PPi, ATP and GTP. These results demonstrate that the enzyme investigated in this study is different from well known ester phosphate cleaving plant enzymes (apyrase and inorganic pyrophosphatases) and this preparation could be a useful tool to future toxicological studies and to study initially all isoforms of acid phosphatase.

Key words: Cucumis sativus, Raphanus sativus, Eruca vesicaria, phosphatases.

\section{RESUMO}

As fosfatases ácidas (3.1.3.2) são um grupo de enzimas amplamente distribuídas na natureza, as quais catalisam a hidrólise de uma variedade de ésteres de fosfato com uma variação de $\mathrm{pH}$ entre quatro e seis. Foi confirmada a presença de fosfatases ácidas em plântulas de pepino (Cucumis sativus), rabanete (Raphanus sativus) e rúcula (Eruca vesicaria) sob diferentes condições de ensaio usando uma preparação rápida e simples. Os resultados mostraram que o $\mathrm{pH}$ e a temperatura ótimos para todas as espécies foram 5,5 e $35^{\circ} \mathrm{C}$, respectivamente. A enzima foi inibida por molibdato, fluoreto, azida, levamisole, ortovanadato, $\mathrm{Zn}^{2+}$ e $\mathrm{Cu}^{2+}$. O inibidor suramim não afetou a atividade enzimática. As fosfatases ácidas de pepino, rabanete e rúcula hidrolisaram uma ampla variedade de ésteres de fosfato e a maior atividade foi observada com PPi, ATP e GTP para pepino e rabanete e PPi, frutose-6fosfato e GTP para rúcula. Esses resultados demonstraram que a enzima investigada neste estudo é diferente das conhecidas enzimas de plantas que clivam ésteres de fosfato (apirase e pirofosfatases inorgânicas). Desse modo, esta preparação pode ser uma ferramenta útil para futuros estudos toxicológicos e para se estudar inicialmente todas as isoformas das fosfatases ácidas.

Palavras-chave: Cucumis sativus, Raphanus sativus, Eruca vesicaria, fosfatases.

\section{INTRODUCTION}

Phosphate plays a vital role in energy transfer and in metabolic regulation. In addition, it has an important role as a constituent of macromolecules such as phospholipids, proteins and nucleic acids. Under conditions of phosphate limitation, the growth and development of plants are particularly damaged (LEFEBVRE etal., 1990).

Acid phosphatases (E.C. 3.1.3.2) are a group of enzymes that catalyze the hydrolysis of a variety of phosphate esters in acidic environments (PARK \& VAN ETTEN, 1986). These enzymes are widely distributed in plants and are related to phosphate supply and metabolism from a vast array of phosphate esters (OLCZAK et al., 2000). In particular, plant acid phosphatases are ubiquitous and have been characterized in roots (PENHEITER et al., 1997), tubers (GELLATLY et al., 1994), seeds (PARK \& VANETTEN,

'Departamento de Química, Centro de Ciências Naturais e Exatas (CCNE), Universidade Federal de Santa Maria (UFSM), 97105-

900, Santa Maria, RS, Brasil. E-mail: mariarosa@smail.ufsm.br. *Autor para correspondência. 
1986), leaves (STASWICK et al., 1994), and suspension cells (LEFEBVRE et al., 1990). Most plant acid phosphatases show little substrate specificity, exhibit an optimum $\mathrm{pH}$ below 6.0, are usually present in multiple forms, and display different biochemical properties (AOYAMA et al., 2001).

In plants, many roles have been postulated for these enzymes, including the release of inorganic phosphate from organic phosphate in the environment (AOYAMA et al., 2001). Several studies have demonstrated that phosphate deficiency in the immediate environment can cause an increase in extracellular phosphatase activity.

Consequently, studies that contribute to a better understanding of the role of acid phosphatases in plants are of particular importance. The objective of the present investigation was to confirm the presence of an acid phosphatase activity in crude and simple preparation to be posterior used in rapid toxicological test in three developing plant species ( 9 days after germination): Cucumis sativus (cucumber), Raphanus sativus radicula (radish) and Eruca vesicaria sativa (rocket salad). These plant species were selected because they have an easy germination in laboratory and are vastly consumed among the population all over the world.

\section{MATERIAL AND METHODS}

Seeds of cucumber (Cucumis sativus), radish (Raphanus sativus) and rocket salad (Eruca vesicaria) were germinated on filter paper and seedlings maintained at a regulated temperature $\left(22-25^{\circ} \mathrm{C}\right)$ and photoperiod $(12 \mathrm{~h} / 12 \mathrm{~h})$. The seedlings make use of seed nutrient in initial stage of the development and it was verified in an initial experiment that, in initial stage, the plants did not suffer severe nutritious deficiency. Samples (whole plants) were collected in the interval of 3 to 15 days after germination. Tissues were ground with a mortar and pestle and the homogenate was filtered and then centrifuged at $43.200 \mathrm{x}$ g for 30 minutes. The supernatant was used for enzyme assay.

The total acid phosphatases activity was determined according to TABALDI et al. (2007). Enzyme specific activities are reported as nmol Pi released/min/ $\mathrm{mg}$ protein. Assays to determine the $\mathrm{pH}$ optimum were done as follow: in the 4.0-6.0 $\mathrm{pH}$ range, $100 \mathrm{mM}$ citrate buffer was used, in the ranges of $\mathrm{pH} 7.0-9.0$ and $\mathrm{pH}$ 10.0-11.0, 100mM Tris/HCl and glycilglycine were used, respectively, with ATP, ADP, PPi and $\beta$-Glycerol phosphate as substrates. Assays to determine the temperature optimal were performed at 15, 25, 37 and $45^{\circ} \mathrm{C}$ with ATP, ADP, PPi and $\beta$-Glycerol phosphate as substrates. Protein was measured by the Coomassie blue method according to BRADFORD (1976).
Substrate curves were determined in the presence of 0.05-5.0mM ATP, ADP and PPi as substrates. ATP, ADP, AMP, bis- $\rho N P P, \beta$-Glycerol phosphate, GTP, fructose-6-phosphate and PPi were used as substrates to determine the substrate specificity to the acid phosphatases activity, each one at a final concentration of $3.0 \mathrm{mM}$.

The sensitivity of acid phosphatases from cucumber, radish and rocket salad to different inhibitors was tested with ATP, ADP, PPi and B-glycerol phosphate as substrate. The inhibitors tested were sodium azide (1.5-5.0mM), sodium fluoride (5.0-20mM), orthovanadate (1.0-10mM), levamisole $(0.5-1.5 \mathrm{mM})$, suramin $(0.03-0.3 \mathrm{mM})$, trifluoperazine $(0.05-0.15 \mathrm{mM})$, and ammonium molybdate (0.1-2.0mM). Divalent cations, calcium, magnesium, cupper and zinc were tested at the 1.0 to $10 \mathrm{mM}$ range in the incubation medium with EDTA (5.0mM). Data were analyzed statistically by one-way analysis of variance followed by the Duncan test when the F test was significant.

\section{RESULTS}

Seedlings at 9 days of age were used for the enzymatic assays for all species because it presented the highest activity (data not shown). The effect of $\mathrm{pH}$ on enzymatic activity of total acid phosphatase, using ATP, ADP PPi or ß-glycerol phosphate as substrate, is presented in figure $1 \mathrm{~A}$. Activity was maximal at $\mathrm{pH}$ 5.06.0 , and sharply decreased at higher $\mathrm{pH}$ values. The $\mathrm{pH}$ selected for the incubation medium for total acid phosphatases was 5.5.

The effect of temperature on the activity of total acid phosphatases from cucumber, radish and rocket salad with ATP, ADP, PPi or ß-glycerol phosphate as substrate is showed in figure 1B. The enzyme from all species showed maximal activity near $37^{\circ} \mathrm{C}$, decreasing at higher temperatures. The temperature of $35^{\circ} \mathrm{C}$ was considered to be safe and was used for later assays.

Total acid phosphatases from cucumber, radish and rocket salad presented a broad substrate specificity (Table 1), showing decreasing order of specificity towards $\mathrm{PPi}>\mathrm{GTP}>\mathrm{ATP}>$ fructose-6phosphate $>A D P>A M P>\beta$-glycerol phosphate $>$ bis$\mathrm{pNPP}$ in cucumber, $\mathrm{PPi}>\mathrm{ATP}>\mathrm{GTP}>\beta$-glycerol phosphate $>$ AMP $>$ fructose-6-phosphate $>$ ADP $>$ bispNPP in radish and $\mathrm{PPi}>$ fructose-6-phosphate $>\mathrm{GTP}>$ $\mathrm{ATP}>\beta$-glycerol phosphate $>$ bis-pNPP $>$ AMP $>$ ADP in rocket salad.

The effects of some compounds acting as inhibitors of apyrase, ATPases and phosphatases were 


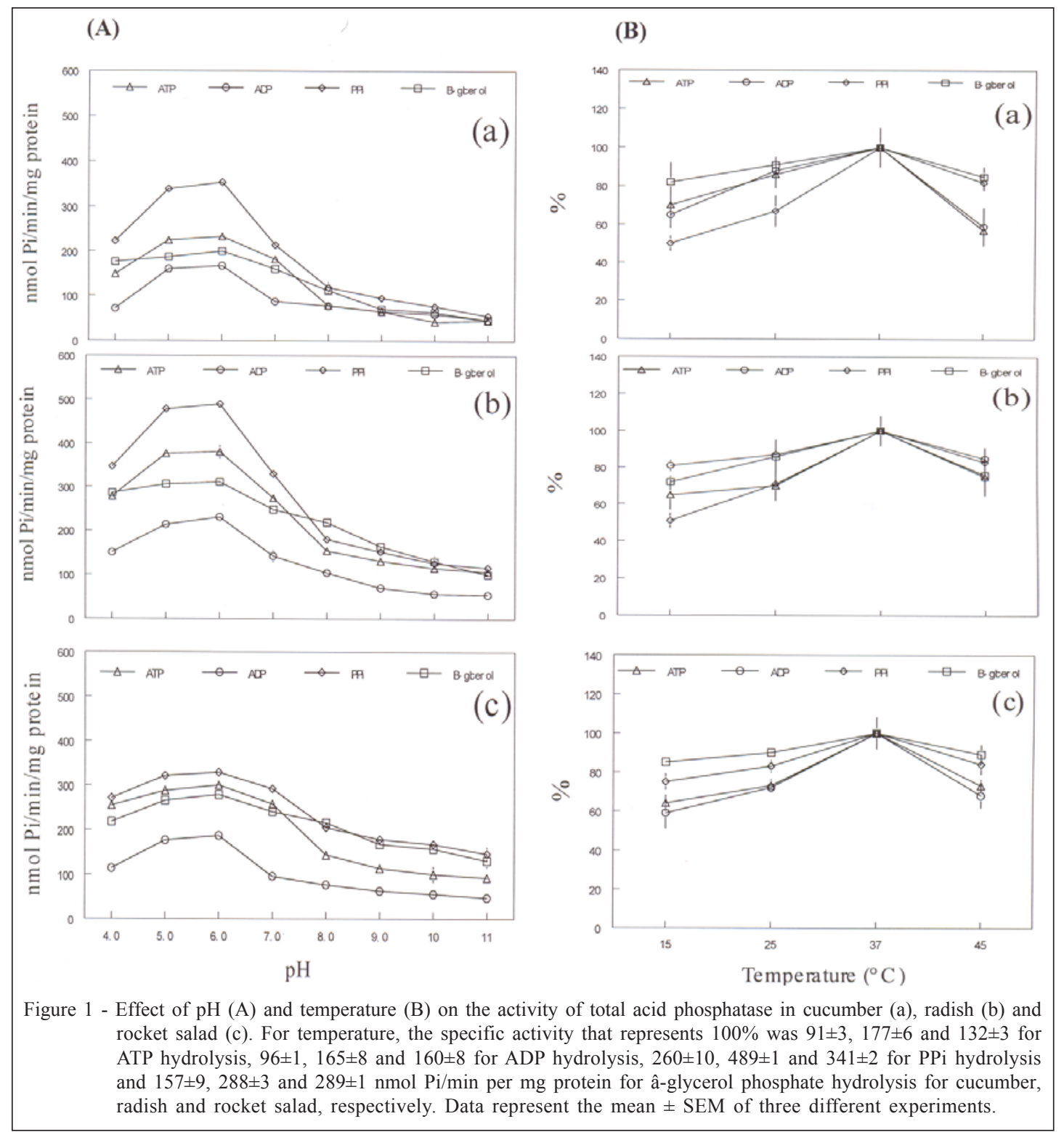

Table 1 - Substrate specificity of total acid phosphatase in cucumber, radish and rocket salad ${ }^{\mathrm{a}}$.

\begin{tabular}{lccc}
\hline & & Relative activity (\%) & Rocket salad \\
\cline { 2 - 4 } Substrate $(3 \mathrm{mM})$ & Cucumber & Radish & 100 \\
\hline ATP & 100 & 100 & 64 \\
ADP & 68 & 33 & 108 \\
GTP & 137 & 68 & 65 \\
AMP & 64 & 37 & 84 \\
B-Glycerol phosphate & 60 & 53 & 83 \\
Bis-pNPP & 48 & 18 & 112 \\
Fructose-6-phosphate & 85 & 34 & 210 \\
PPi & 248 & 103 & \\
\hline
\end{tabular}

${ }^{a}$ Results represent the means for at least three different preparations. The specific activity that represents $100 \%$ (ATP) was $281 \pm 6,965 \pm 8$ and $396 \pm 9 \mathrm{nmol} \mathrm{Pi} / \mathrm{min} / \mathrm{mg}$ protein for cucumber, radish and rocket salad, respectively.

Ciência Rural, v.38, n.3, mai-jun, 2008. 
studied in cucumber, radish and rocket salad. The enzyme was inhibited by typical phosphatases inhibitors (OLCZAK et al., 2000) such as fluoride (Figure 2A), molybdate (Figure 2B) and levamisole (Figure 3A), with inhibition occurring at all concentrations tested $(\mathrm{P}<0.05)$, except with levamisole at $0.5 \mathrm{mM}$ in rocket salad. Orthovanadate, an inhibitor of acid phosphatase (BABU et al., 2002), also inhibited the acid phosphatases in all preparations tested (Figure 3B).
Sodium azide, an inhibitor of mitochondrial ATPase (F type ATPase) (PEDERSEN, 1975), inhibited ATP, ADP, PPi and $\beta$-glycerol phosphate hydrolysis in all preparations tested, with more pronounced inhibition at concentrations of 3.0 and $5.0 \mathrm{mM}$ (Figure $4 \mathrm{~A})(\mathrm{P}<$ $0.05)$. Suramin $(0.03-0.3 \mathrm{mM})$, an apyrase inhibitor (SCHETINGER et al., 2001) did not affect ATP, ADP, PPi or $\beta$-glycerol phosphate hydrolysis at any of the concentrations tested (data not shown), while trifluoperazine, an inhibitor of membrane $\mathrm{Ca}^{2+}$-ATPase,

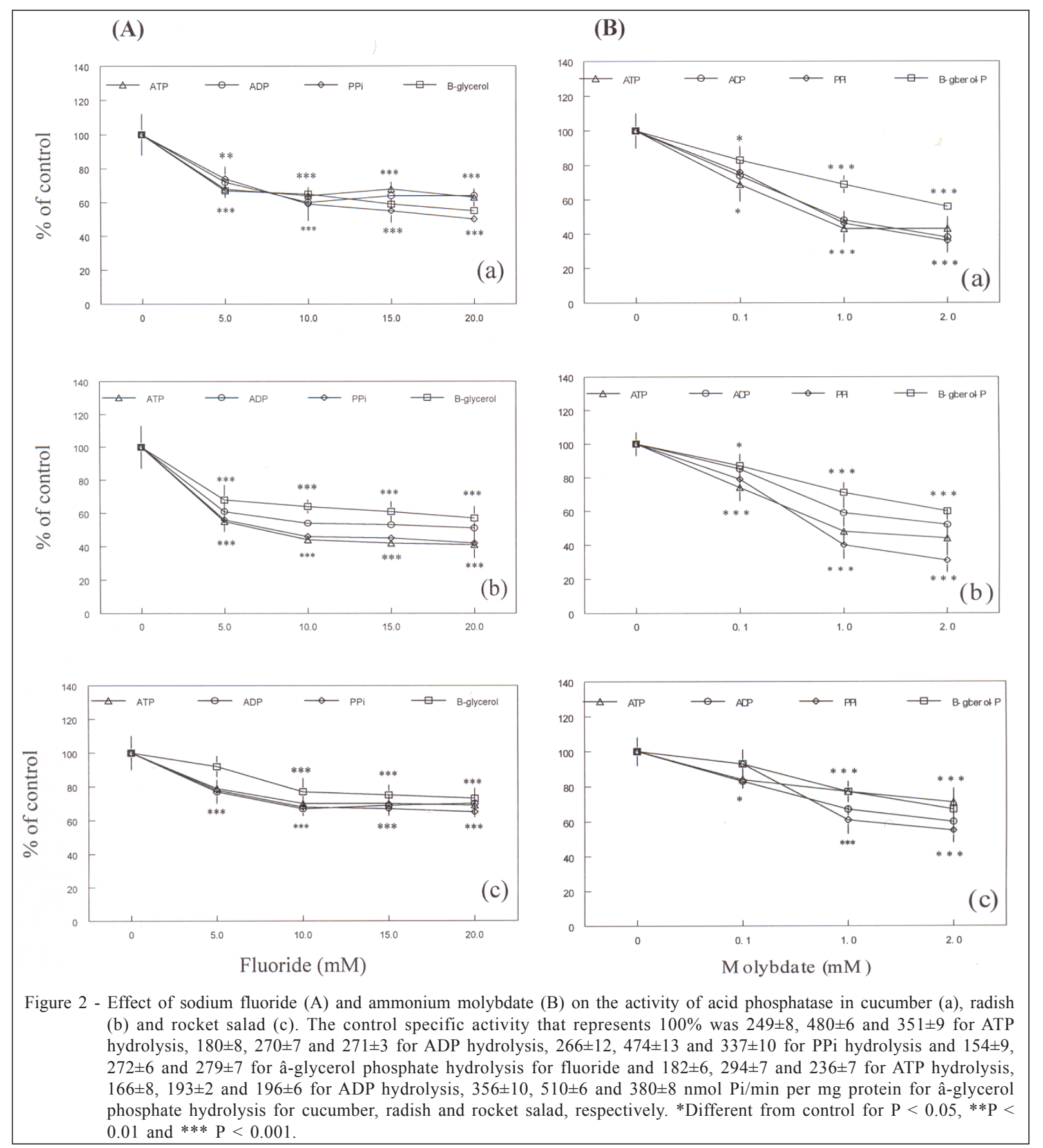

Ciência Rural, v.38, n.3, mai-jun, 2008. 


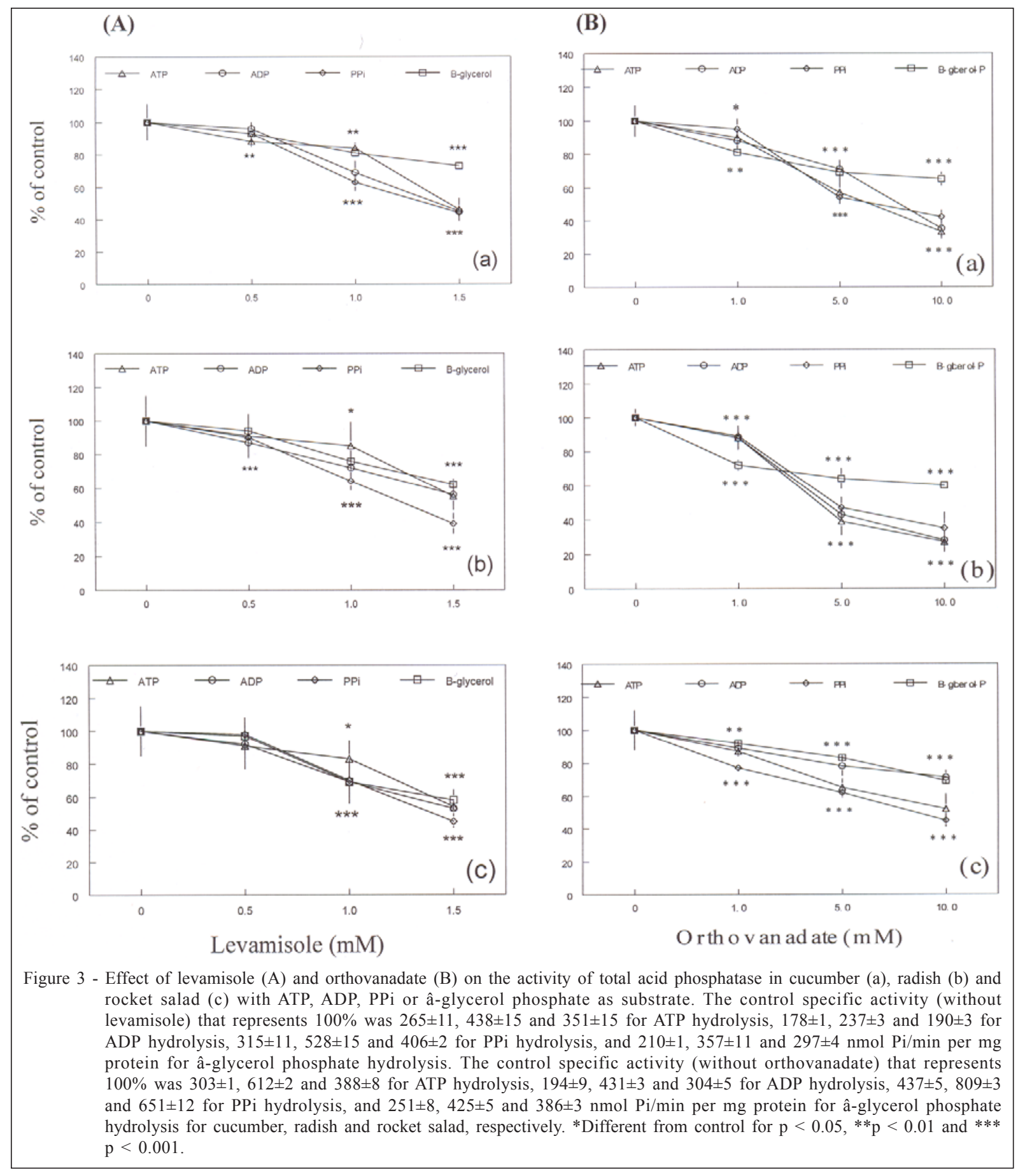

inhibited only at concentrations of 0.1 and $0.15 \mathrm{mM}$. At $0.1 \mathrm{mM}$, trifluoperazine inhibited the hydrolysis of ATP and ADP in cucumber and rocket salad, and the hydrolysis of ATP, ADP and PPi in radish. Trifluoperazine also inhibited ADP and PPi hydrolysis in cucumber, with all substrates in radish and of PPi and with $\beta$-glycerol phosphate in rocket salad at $0.15 \mathrm{mM}$ (Figure 4B).
In addition, some divalent cations such as $\mathrm{Cu}^{2+}, \mathrm{Zn}^{2+}, \mathrm{Ca}^{2+}$ and $\mathrm{Mg}^{2+}(1.0,2.5,5.0$ and $10.0 \mathrm{mM})$ were tested with EDTA (5.0mM) (Table 2). In such condition, $\mathrm{Cu}^{2+}$ and $\mathrm{Zn}^{2+}$ had inhibitory actions on the enzyme activity at high concentrations $(10 \mathrm{mM})$ in cucumber, radish and rocket salad. However, $\mathrm{Ca}^{2+}$ and $\mathrm{Mg}^{2+}$ had stimulatory effects when used at $2.5 \mathrm{mM}$ and $5.0 \mathrm{mM}$ plus EDTA 5.0mM. Therefore, in all assays we

Ciência Rural, v.38, n.3, mai-jun, 2008. 


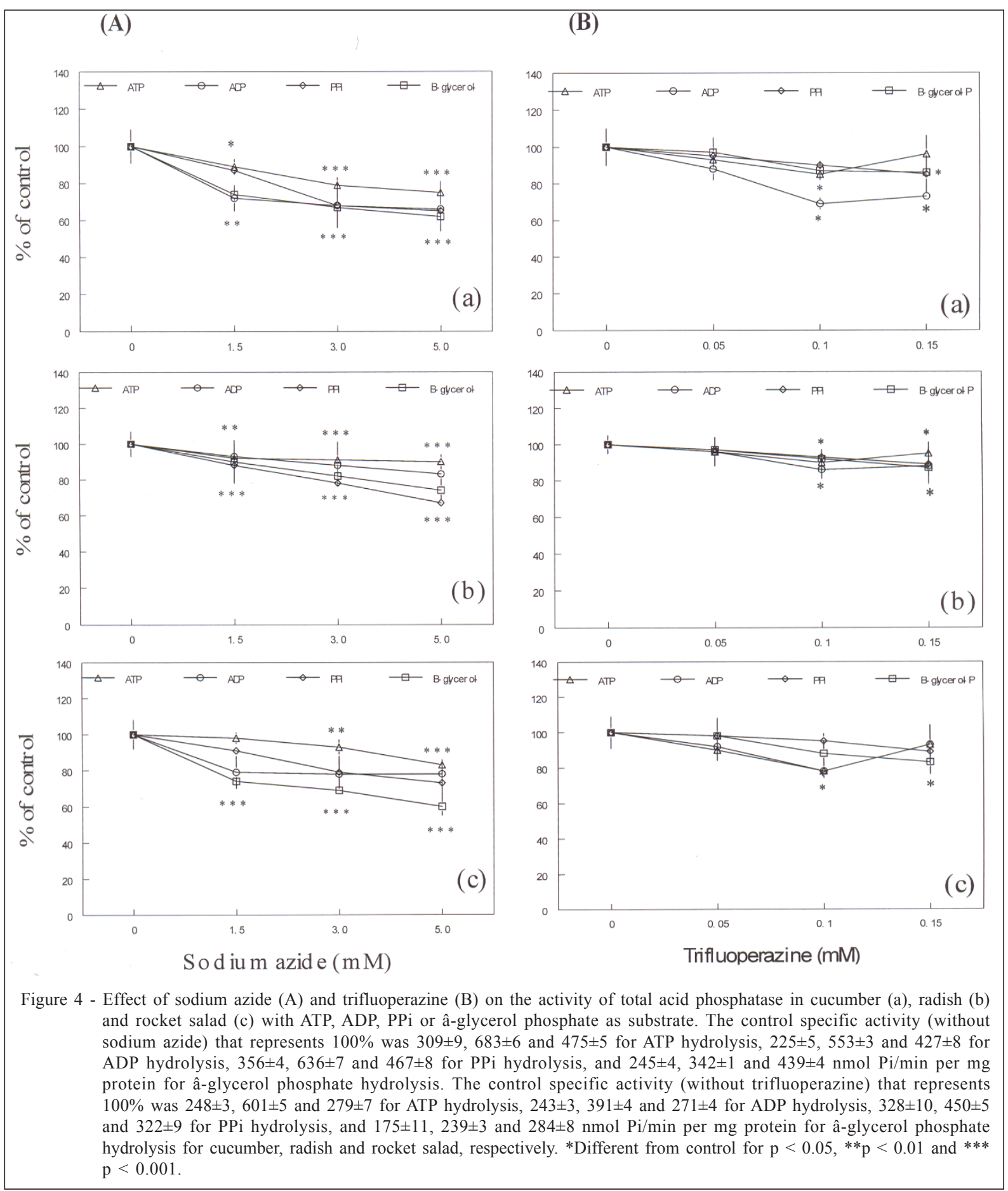

added a divalent cation $\left(\mathrm{Ca}^{2+}\right)$ at $2.5 \mathrm{mM}$ plus EDTA $5.0 \mathrm{mM}$.

\section{DISCUSSION}

Total acid phosphatases from these three species presented a similar response in terms of germination time to obtain the highest activity, $\mathrm{pH}$, temperature, incubation time and effect of inhibitors, and a distinct response in terms of substrate specificity. A period of nine days after germination was selected for the assays because it presented the highest activity. The best temperature for acid phosphatases incubation was $37^{\circ} \mathrm{C}$, being similar to that described for some plant acid phosphatases, such as barley roots $\left(30-35^{\circ} \mathrm{C}\right)$ (PANARA et al., 1990), and cotton seed $\left(37^{\circ} \mathrm{C}\right)$ 
Table 2 - Effect of metal ions and EDTA (5.0mM) on the activity of acid phosphatase from cucumber, radish and rocket salad, with ATP as substrate $^{\mathrm{a}}$.

\begin{tabular}{|c|c|c|c|c|c|}
\hline & \multirow{2}{*}{ Addition } & \multicolumn{4}{|c|}{ Relative activity ( $\%$ of control) } \\
\hline & & $1.0 \mathrm{mM}$ & $2.5 \mathrm{mM}$ & $5.0 \mathrm{mM}$ & $10.0 \mathrm{mM}$ \\
\hline \multirow{5}{*}{ Cucumber } & $\mathrm{Mg}^{2+}+$ EDTA & $112^{*}$ & $129^{* * *}$ & $112^{*}$ & 103 \\
\hline & $\mathrm{Ca}^{2+}+$ EDTA & 104 & $115^{* *}$ & $121^{* * *}$ & 106 \\
\hline & $\mathrm{Zn}^{2+}+\mathrm{EDTA}$ & 111 & 107 & $86^{* *}$ & $85^{* *}$ \\
\hline & $\mathrm{Cu}^{2+}+$ EDTA & 113 & 95 & 91 & 85 \\
\hline & EDTA & $62^{* * *}$ & $55^{* * *}$ & $45^{* * *}$ & $35^{* * *}$ \\
\hline \multirow{5}{*}{ Radish } & $\mathrm{Mg}^{2+}+$ EDTA & $110^{* * *}$ & $131^{* * *}$ & $109^{* * *}$ & 99 \\
\hline & $\mathrm{Ca}^{2+}+$ EDTA & 101 & $124^{* * *}$ & $132^{* * *}$ & 104 \\
\hline & $\mathrm{Zn}^{2+}+$ EDTA & 99 & 108 & 101 & $91^{* * *}$ \\
\hline & $\mathrm{Cu}^{2+}+$ EDTA & 104 & 99 & 94 & $84^{* * *}$ \\
\hline & EDTA & 97 & 95 & $84^{* *}$ & $75^{* * *}$ \\
\hline \multirow{5}{*}{ Rocket Salad } & $\mathrm{Mg}^{2+}+$ EDTA & $119^{* * *}$ & $128^{* * *}$ & $122^{* * *}$ & 104 \\
\hline & $\mathrm{Ca}^{2+}+$ EDTA & 106 & $126^{* * *}$ & $151^{* * *}$ & 100 \\
\hline & $\mathrm{Zn}^{2+}+$ EDTA & 101 & 108 & 101 & $82^{* * *}$ \\
\hline & $\mathrm{Cu}^{2+}+$ EDTA & 104 & $87^{* * *}$ & $81^{* * *}$ & $72^{* * *}$ \\
\hline & EDTA & $81^{* * *}$ & $80^{* * *}$ & $71^{* * *}$ & $65^{* * *}$ \\
\hline
\end{tabular}

${ }^{a}$ Results represent the values obtained of three different experiments. Specific activity that represents $100 \%$ (no addition metal ion or EDTA) is $245 \pm 10,527 \pm 6$ e $360 \pm 8 \mathrm{nmol}$ Pi released/min per mg of protein to cucumber, radish and rocket salad, respectively. ${ }^{*}$ Different from control for $\mathrm{P}<0.05, * * \mathrm{P}<0.01$ and $* * * \mathrm{P}<0.001$.

(BHARGAVA\& SACHAR, 1987). We preferred to work at $35^{\circ} \mathrm{C}$ to avoid some thermal inactivation, as observed at temperatures higher than $37^{\circ} \mathrm{C}$ (Figure 1B).

In the $\mathrm{pH}$ dependence study with 3mMATP, ADP, PPi or $\beta$-glycerol phosphate as substrate, acid phosphatases presented the same range of optimum $\mathrm{pH}$ for cucumber, radish and rocket salad, with maximal activity around $\mathrm{pH} 5.0-6.0$, decreasing in the $\mathrm{pH}$ range above 7.0. These data are closely related to those obtained using $\rho$ NPP as substrate in the phosphatase from sunflower seeds (PARK \& VAN ETTEN, 1986). The $\mathrm{pH}$ dependence of the enzyme activity may be an important aspect of the control of plant metabolism (FERREIRA et al., 1999).

The acid phosphatases for the three species were inhibited by molybdate, fluoride, azide, levamisole, orthovanadate, and, to a lesser extent, by trifluoperazine. Suramin had no effect on the enzyme activity. Molybdate and fluoride are strong plant acid phosphatase inhibitors (FERREIRA et al., 1999), inhibiting also the acid phosphatase in yellow lupin seeds (OLCZAK et al., 2000). The results obtained with $\mathrm{Zn}^{2+}$ and $\mathrm{Cu}^{2+}$ were similar to those reported in the literature, with these divalent cations being potent inhibitors of soybean acid phosphatases (FERREIRA et al., 1999). In tests carried out in our laboratory, $\mathrm{Zn}^{2+}$ was one of the most potent inhibitors of acid phosphatases in cucumber seedlings (TABALDI et al., 2007). However, when some metals such as calcium and magnesium were used with EDTA, they acted as activators of acid phosphatases. Taken together, the results obtained with the study of $\mathrm{pH}$ and of the effects of inhibitors and divalent cations confirm the predominant presence of acid phosphatases in our preparation.

Acid phosphatase has been shown to have broad substrate specificity, with PPi, ATP and GTP as the preferred substrates. ATP and PPi have been shown to be the preferred substrates for a number of acid phosphatases already characterized. Acid phosphatases with wide substrate specificity are proposed to be involved in mining/recycling leaked $\mathrm{P}$ containing compounds.

Thus, our results propose a possible new approach to acid phosphatases study in plants based on the metabolism of common phosphate donors in plants. In fact, in this study pure enzyme preparations were not used and, as a consequence, the presence of multiple isoforms is imprecise. It is known that crude extracts could contain multiple forms of acid phosphatases and the results obtained probably are an association among these isoforms. Moreover, the 
crude extract was likely to contain factors that affect the enzymatic activity of this enzyme. However, it did not decline the importance of the results obtained in this work.

From all the data presented above, we may conclude that acid phosphatase from cucumber, radish and rocket salad is a nonspecific enzyme responding similarly to a variety of factors. This enzyme has been studied in plants because of its involvement in the metabolism of phosphorus, which is essential for normal growth and development of plant organs. Therefore, this preparation could be a useful tool to future toxicological studies and to study initially all isoforms of acid phosphatase.

\section{REFERENCES}

AOYAMA, H. et al. Endogenous lectin as a possible regulator of the hydrolysis of physiological substrates by soybean seed acid phosphatase. Phytochemistry, v.58, p.221-225, 2001.

BABU, M.M. et al. Shigella apyrase - a novel variant of bacterial acid phosphatase? FEBS Letters, v.512, p.8-12, 2002.

BHARGAVA, R.; SACHAR, R.C. Induction of acid phosphatase in cotton seedlings: enzyme purification, subunit structure and kinetic properties. Phytochemistry, v.26, p.1293-1297, 1987.

BRADFORD, M.M. A rapid and sensitive method for the quantitation of microgram quantities of protein utilizing the principle of protein-dye binding. Analytical Biochemistry, v.72, p.248-254, 1976 .

FERREIRA, C.V. et al. Glycolytic intermediates as substrates of soybean acid phosphatase isoforms. Plant Science, v.147, p.49-54, 1999.
GELLATLY, K. et al. Purification of a potato tuber acid phosphatase having characteristics of a protein tyrosine phosphatase. Plant Physiology, v.106, p.223-232, 1994.

LEFEBVRE, D.D. et al. Response to phosphate deprivation in Brassica nigra suspension cells. Enhancement of intracellular, cell surface and secreted phosphatase activities compared to increases in Pi-absorption rate. Plant Physiology, v.93, p.504511,1990 .

OLCZAK, M. et al. Characterization of diphosphonucleotide phosphatase/phosphodiesterase from yellow lupin (Lupinus luteus) seeds. Biochimica et Biophysica Acta, v.1478, p.239247, 2000.

PANARA, F. et al. Multiple forms of barley root acid phosphatase: purification and some characteristics of the major cytoplasmic isoenzyme. Biochimica et Biophysica Acta, v.1037, p.73-80, 1990

PARK, H.C.; VAN ETTEN, R.L. Purification and characterization of homogeneous sunflower seed acid phosphatase. Phytochemistry, v.25, p.351-357, 1986.

PEDERSEN, P.L. Mitochondrial adenosine triphosphatase. Bioenergetics, v.6, p.243-275, 1975.

PENHEITER, A.R. et al. Soybean root nodule and acid phosphatase. Plant Physiology, v.114, p.597-604, 1997.

SCHETINGER, M.R.C. et al. ATP and ADP hydrolysis in fish, chicken and rat synaptosomes. Comparative Biochemistry and Physiology, v.128, p.731-741, 2001.

STASWICK, P.E. et al. Purification of the major soybean leaf acid phosphatase that is increased by seed-pod removal. Plant Physiology, v.104, p.49-57, 1994.

TABALDI, L.A. et al. Effects of metal elements on acid phosphatase activity in cucumber (Cucumis sativus L.) seedlings. Environmental and Experimental Botany, v.59, p.43-48, 2007. 